\title{
Nutritional knowledge and body mass index: A cross-sectional study
}

\author{
Julia Luzzı Valmórbida ${ }^{1}$, Maíra Ribas Goulart ${ }^{1}$, Fernanda Michielin Busnello ${ }^{1}$, Lúcia Campos Pellanda ${ }^{1} 2^{*}$ \\ ${ }^{1}$ Universidade Federal de Ciências da Saúde de Porto Alegre (UFCSPA), Porto Alegre, RS, Brazil \\ ${ }^{2}$ Instituto de Cardiologia do Rio Grande do Sul/Fundação Universitária de Cardiologia (IC/FUC), Porto Alegre, RS, Brazil
}

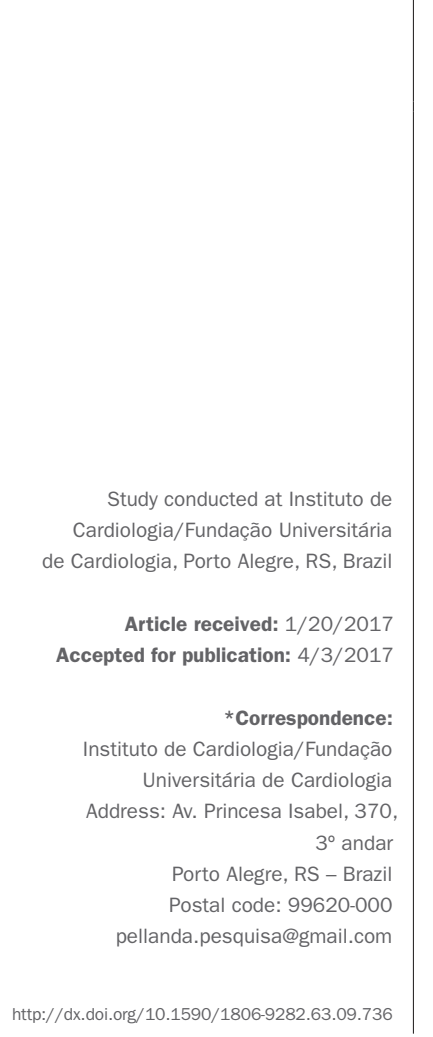

\section{SUMMARY}

Objective: To verify the knowledge about food and nutrition and its association with the nutritional status of obese patients with noncommunicable diseases (NCDs), and to identify the relationship between information sources and level of knowledge.

Method: Cross-sectional study that included 263 outpatients of a cardiology referral hospital in Porto Alegre, Rio Grande do Sul, Brazil. The participants filled out a questionnaire on socioeconomic data and knowledge about food and nutrition and had their nutritional status evaluated by body mass index (BMI), waist circumference (WC) and waist-hip ratio (WHR).

Results: BMI showed a significant inverse association with the percentage of correct answers ( $\mathrm{p}=0.002)$, as well as WC $(\mathrm{p}=0.000)$ and WHR $(\mathrm{p}<0.001)$. This was also true for education $(\mathrm{p}<0.001)$ and female gender $(\mathrm{p}=0.005)$ compared to males. More than $60 \%$ of patients reported using television and $23 \%$ reported using newspaper as sources of nutritional information.

Conclusion: Our study revealed a significant association between BMI and the level of knowledge about foods, showing that there is need for more information on obesity-related NCDs for greater understanding by patients.

Keywords: obesity, knowledge, attitudes and health practices, nutrition, chronic disease.

\section{INTRODUCTION}

Chronic noncommunicable diseases (CNCD) were responsible for 38 million deaths worldwide in 2012. ${ }^{1}$ These include diabetes mellitus (DM) and high blood pressure (HBP). It is known that an increased body mass index (BMI) is related to an increase in CNCDs and that the specific treatment of obesity can also act in the control of other CNCDs. ${ }^{2}$ In Brazil, 12.5\% of men and 16.9\% of women are obese. ${ }^{3}$ Therefore, weight loss is a primary goal in public health strategies directed to this population.

In order to promote healthier eating habits and improve self-care regarding $\mathrm{CNCD}$, it is important for the population to gain knowledge about food and nutrition, ${ }^{46}$ especially those related to healthy food choices and nutritional recommendations. ${ }^{7}$ Several studies have found a relationship between dietary knowledge and obesity, ${ }^{8-11}$ as well as nutritional status. ${ }^{12}$

Considering that the understanding of these issues is important for advancing the treatment of CNCDs, the objective of our study is to describe the knowledge about diet and nutrition and its relation with the nutritional status of obese patients with CNCD who attend a cardiology outpatient clinic.

\section{Method}

\section{Patients}

This cross-sectional study was carried out with patients attending the general outpatient clinic of the SUS (Brazilian public health system) in a reference hospital randomly selected between May and July 2009. The sample was calculated using a $95 \%$ confidence interval, with a margin of error of $6 \%$, estimating an average of $70 \%$ of correct answers in the questionnaire, resulting in a minimum of 225 patients. Considering the possibility of losses, the final sample consisted of 263 patients.

Patients with BMI greater than or equal to $30 \mathrm{~kg} / \mathrm{m}^{2}$, individuals aged 20 years or older and who agreed to participate by signing a Free and Informed Consent Form (FICF) were included. 
Patients who presented diseases that caused obesity and water retention, presence of edema, liver disease or nephropathy were excluded. Our study was approved by the institution's ethics committee.

\section{Data collection procedure}

Nutritional status was evaluated based on BMI, waist circumference (WC) and the waist-hip ratio (WHR). In order to measure weight and height, participants were positioned on their feet, with their heels joined, arms along their sides, legs stretched, shoulders relaxed, and head in the horizontal plane; they were all barefoot and wearing light clothing. Both height and weight were measured using an anthropometric scale, Filizola brand, located in a private place, in the waiting room of the outpatient clinic. WC was measured while the patient was standing up, just after breathing out, $1 \mathrm{~cm}$ above the iliac crest. Hip circumference was assessed on the widest circumference of the buttocks. All of these measurements were performed with an inelastic tape measure.

After the anthropometric evaluation, the patients answered a questionnaire with thirteen questions. The questionnaire was initially consisted of questions about personal and sociodemographic identification, such as sex, age, formal education, risk factors, food choice and sources of food information. There were also 20 questions to assess the level of general knowledge about food and nutrition, such as sugar, fat, fiber and salt content in foods, as well as sources of dietary cholesterol. The questionnaires were applied by a researcher trained for such activity in the waiting room of the outpatient clinic.

The questionnaire was adapted from Parmenter and Wardle,$^{13}$ since there were no other similar studies applied in the adult Brazilian population. Questions about sources of information about foods and influences on food choice were multiple choice, with the possibility of selecting more than one option for each of the questions, as well as questions concerning sugar, fat and sodium contents in foods. In all other questions about diet and nutrition, patients could select only one of the alternatives presented.

\section{Statistical analysis}

The database was assembled using Excel 2003, while the statistical analyzes were performed using SPSS software version 17.0.2.

Means and standard deviation or median and minimum and maximum values were used to present continuous variables, while absolute (n) and relative (\%) frequencies were used for the categorical variables. Continuous variables were analyzed using Pearson correlation, and categorical variables were analyzed using Spearman correlation. We used Student's t-test to compare means, and Chi-square test to analyze associations. In all comparisons, a critical alpha of 0.05 was considered.

\section{Results}

The study totaled 263 participants. The sample was consisted of $52 \%$ of female subjects, with $66.5 \%$ of married individuals. Regarding education, $43.4 \%$ reported not having completed elementary school. The mean age was 56.7 years and the mean BMI was in the obesity range $\left(32.48 \mathrm{~kg} / \mathrm{m}^{2}\right)$, as shown in Table 1 . The general characteristics of the population are presented in Table 1. BMI, WC and WHR of both sexes are described in Table 2. The mean of correct responses according to different characteristics is described in Figure 1.

TABLE 1 General characteristics of the population.

\begin{tabular}{ll} 
Variables & $\mathbf{N}(\%)$ \\
\hline Female & $138(52.5)$ \\
\hline Married & $175(66.5)$ \\
\hline Elementary school, incomplete & $114(43.4)$ \\
\hline High school diploma & $70(26.6)$ \\
\hline & $\mathrm{N} \pm \mathrm{SD}$ \\
\hline Mean age & $56.7 \pm 12.9$ years \\
\hline Mean BMI & $32.48 \pm 3.41 \mathrm{~kg} / \mathrm{m}^{2}$ \\
\hline
\end{tabular}

SD: standard deviation.

TABLE 2 Mean BMI, WC and WHR for men and women.

\begin{tabular}{llll} 
& BMI $\left(\mathbf{k g} / \mathbf{m}^{2}\right)$ & WC $(\mathbf{c m})$ & WHR \\
\hline Women & $33.36 \pm 4.2$ & $109.92 \pm 10.11$ & $0.95 \pm 0.05$ \\
\hline Men & $32.26 \pm 2.1$ & $112.57 \pm 7.43$ & $1.00 \pm 0.05$ \\
\hline Total of the sample & $32.84 \pm 3.41$ & $111.09 \pm 9.00$ & $0.97 \pm 0.06$ \\
\hline
\end{tabular}

BMI: body mass index; WC: waist circumference; WHR: waist-hip ratio.

The BMI showed an inverse and significant association with the percentage of correct answers ( $\mathrm{p}=0.002)$, as well as WC $(\mathrm{p}<0.001)$ and WHR $(\mathrm{p}<0.001)$. However, after stratification by sex, there was a significant association between women when correlating the percentage of correct answers with BMI $(\mathrm{p}<0.001)$ and WC $(\mathrm{p}<0.001)$. Among men, there was a significant association between the percentage of correct answers and WHR $(\mathrm{p}=0.002)$.

Regarding "dieting or adopting food restrictions," $39.2 \%$ (103) answered affirmatively. Nevertheless, $88.2 \%$ of the participants stated that they presented some CNCD in addition to obesity. 


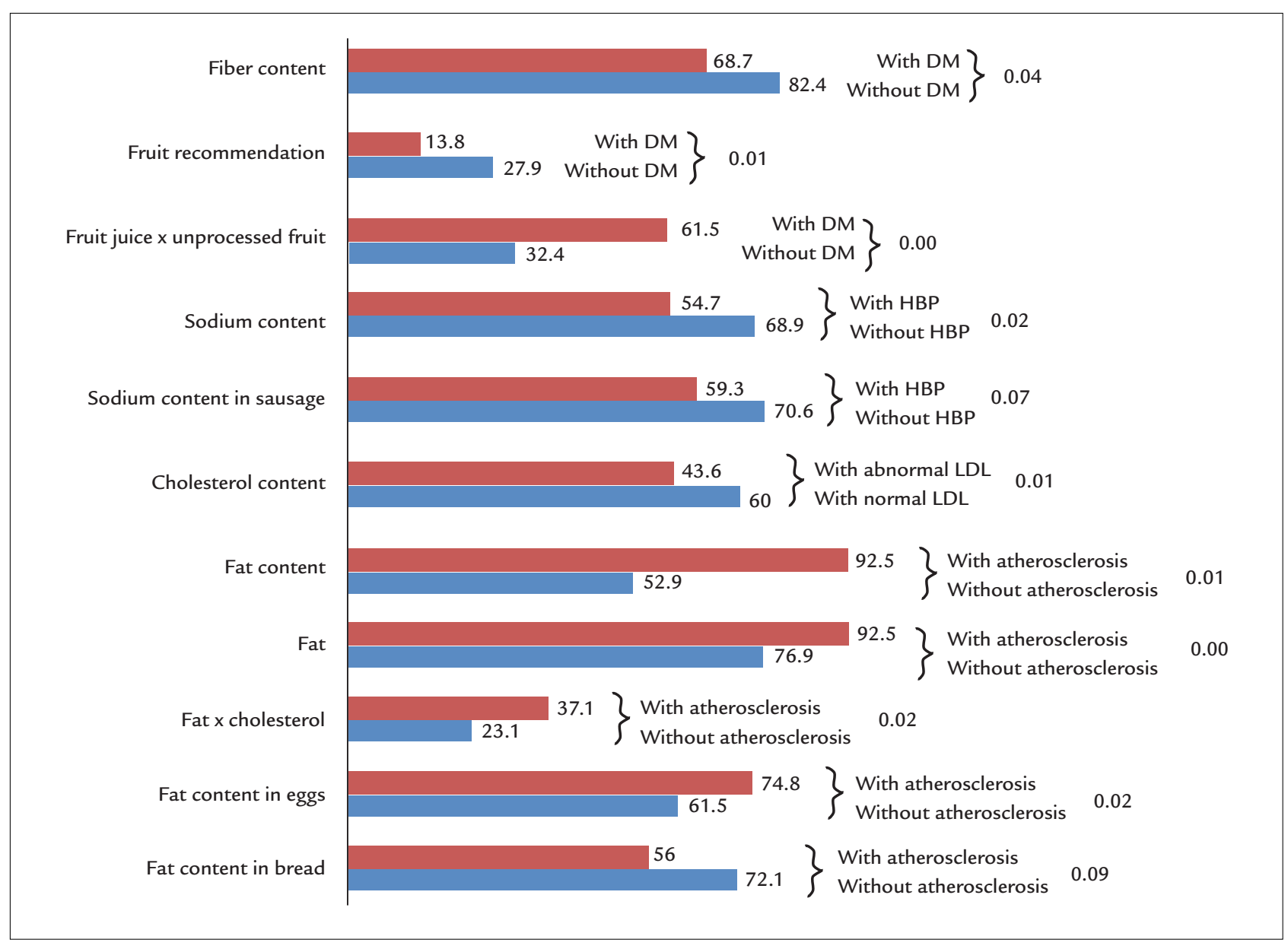

FIGURE 1 Relation between the presence of chronic noncommunicable disease and the mean of correct responses in percentages and p-value.

When asked about the factors that most influence food choice, the most commonly reported alternative was "attempt to maintain a healthy diet" (53\%), followed by "taste of the food" (31\%) and "routine" (24\%). The level of knowledge of the patients who chose the alternative "taste" as one of the main influences in food choice was significantly lower than those who did not choose this alternative. Those who claimed to choose food items in accordance to a diet or to follow a healthy diet had a higher degree of knowledge than those who did not.

Regarding the main sources of information about food and nutrition, $67.3 \%$ of the patients (177) pointed to television as one of the main sources, followed by health professionals (29\%), newspaper $(23 \%)$ and nutritionists (16\%).

\section{Discussion}

The main finding in our study was an inverse and significant correlation between BMI and WC/WHR, as well as the percentage of the participants' correct answers.
Even though some findings do not corroborate the results of the study, ${ }^{14-18}$ these are still relevant data. By demonstrating that the level of knowledge about food and nutrition has a significant impact on the nutritional status (noting that participants who scored less in the questionnaire had the worst results for BMI, WC and WHR), we can justify the importance of developing public policies to raise awareness of healthy eating habits and self-care among individuals presenting CNCDs.

In our study, both men and women had high WC and WHR. WC and WHR have a known relation with the amount of abdominal fat, and high values are indicators of risk for the development of cardiovascular disease.

The participants obtained a middling score on the questionnaire, similar to that found in other studies, ${ }^{19,20}$ except for O'Brien et al., ${ }^{21}$ who found a good level of knowledge. Formal education was related to the mean of correct answers, and low levels of education are probably related to the result found, which is in agreement with the literature..$^{22}$ Differently from another study, our results showed 
that women performed better, ${ }^{23}$ which can be explained by a culture in which women are responsible for buying food and preparing meals for the whole family. ${ }^{17}$

Among the three main sources of food information, two are media-related. It is known that media exposure can influence the food choices of adults as well as the amount of food, and the time spent in front of a television screen is related to the higher consumption of high energy foods. ${ }^{16,24,25}$ Participants who chose "health professionals" or "nutritionists" among the alternatives as important sources of information on food and nutrition did not perform better than those who did not mention these professionals as relevant sources. This reinforces once again the importance of health professionals paying special attention to the diet of patients, especially those with CNCDs.

Most study participants stated that food choice is heavily influenced by an attempt to maintain a healthy diet, even though only $39.2 \%$ indicates any food restriction. However, pointing out that eating choice is influenced by the attempt to maintain a healthy diet or to lose weight resulted in a higher percentage of correct responses. Thus, these patients are probably really concerned with choosing the foods that will be part of their meal, and in order to achieve that goal one must know and take an interest in nutritional recommendations, which is achieved through behavioral programs and nutritional education. ${ }^{26}$

The performance of participants for whom food choice is made primarily based on the taste of food was worse than those who did not choose this alternative. This finding is quite consistent in showing less concern about the items that will make up the meals and the diet as a whole, which also reflects less attention and interest in getting information on this subject.

More than $90 \%$ of patients correctly answered questions of a more general nature and those involving sodium and fat content of certain foods. However, some aspects should be considered: $88.2 \%$ of the patients reported having some other CNCD besides obesity and only $39.2 \%$ are doing some type of dietary control. Less than $10 \%$ of the participants had already heard about the "Food Guide for the Brazilian Population" or the "Ten steps for a healthy diet," materials developed by the Ministry of Health, which should be used for food guidance and advice for Brazilians. Finally, less than $30 \%$ of the patients stated that a physician or other health professional was among the main sources of information about nutrition, this shows that this topic should be further developed at the time of the consultations and that access to nutrition needs to be expanded. This accounts for the fact that nearly $40 \%$ of patients claim to believe that soft drinks are fattier than milk. Therefore, it is up to the health professional to guide patients by indicating educational programs ${ }^{27}$ that address issues related to the importance of a varied diet to control risk factors ${ }^{28}$ and the nutritional composition of foods, especially for lipids, which are important risk factors for coronary artery disease. ${ }^{8}$

The questionnaire used in our study is considered a limitation, since there is no valid instrument for this population and, therefore, we needed to adapt a previously developed instrument.

\section{Conclusion}

There was a significant association between the degree of knowledge about diet and the BMI of the participants, demonstrating the need to develop the autonomy of patients with CNCD, especially with respect to generating knowledge that enables healthy food choices, implementing programs for disease prevention and health promotion.

\section{ACKNOWLEDGMENTS}

We thank the IC/FUC, especially the PREVINA research group, the CAPES and the CNPq.

\section{Resumo}

Conhecimento nutricional e índice de massa corporal: um estudo transversal

Objetivo: Verificar os conhecimentos sobre alimentação e nutrição e sua associação com o estado nutricional de pacientes obesos portadores de doenças crônicas, e identificar a relação das fontes de informação com o nível de conhecimentos.

Método: Estudo transversal realizado com 263 pacientes ambulatoriais de um hospital de referência em cardiologia em Porto Alegre, RS. Os indivíduos preencheram um questionário sobre dados socioeconômicos e conhecimentos sobre alimentação e nutrição, tendo seu estado nutricional avaliado por meio de índice de massa corporal (IMC), circunferência da cintura (CC) e relação cintura quadril (RCQ).

Resultados: O IMC apresentou associação inversa e significativa com o percentual de acertos $(\mathrm{p}=0,002)$, assim como a CC $(\mathrm{p}<0,001)$ e a RCQ $(\mathrm{p}<0,001)$. E também a escolaridade $(\mathrm{p}<0,001)$ e o sexo feminino $(\mathrm{p}=0,005) \mathrm{em}$ relação ao masculino. Mais de $60 \%$ dos pacientes relataram utilizar televisão e $23 \%$ jornal como fontes de informação sobre alimentação.

Conclusão: No presente estudo, houve associação significativa entre IMC e nível de conhecimento sobre alimentação, demonstrando que há necessidade de maior 
divulgação sobre as doenças crônicas não transmissíveis (DCNT) para que haja maior entendimento por parte dos pacientes.

Palavras-chave: obesidade, conhecimentos, atitudes e práticas em saúde, nutrição, doença crônica.

\section{References}

1. World Health Organization. Global Status Report on Noncommunicable Diseases. Geneva: World Health Organization; 2014.

2. Kearns K, Dee A, Fitzgerald AP, Doherty E, Perry IJ. Chronic disease burden associated with overweight and obesity in Ireland: the effects of a small BMI reduction at population level. BMC Public Health. 2014; 14:143.

3. Instituto Brasileiro de Geografia e Estatística. IBGE. Pesquisa de orçamentos familiares 2008-2009 - POF. Rio de Janeiro; 2010 [cited 2016 Oct 23]. Available from: https://biblioteca.ibge.gov.br/visualizacao/livros/liv45419.pdf

4. Triches MR, Giugliani ERJ. Obesidade, práticas alimentares e conhecimentos de nutrição em escolares. Rev Saúde Pública. 2005; 39(4):541-7.

5. Teixeira JF, Goulart MR, Busnello FM, Pellanda LC. Hypertensives' knowledge about high-sodium foods and their behavior. Arq Bras Cardiol. 2016; 106(5):404-10.

6. Pereira DA, Costa NMSC, Sousa ALL, Jardim PCBV, Zanini CRO. The effect of educational intervention on the disease knowledge of diabetes mellitus patients. Rev Latinoam Enferm. 2012; 20(3):478-85.

7. Gomes, ACM, Dias CP, Guerra RO, de Salvo MA. Impacto de estratégias de educação nutricional sobre variáveis antropométricas e conhecimento alimentar. Rev Bras Promoção Saúde. 2013; 26(4):462-9.

8. Girois SB, Kumanyika SK, Morabaia A, Mauger E. Comparison of knowledge and attitudes about diet and health among 35- to 75-year/old adults in the United States and Geneva, Switzerland. Am J Publ Health. 2001; 91(3):418-24.

9. Gordon-Larsen P. Obesity-related knowledge, attitudes, and behaviors in obese and non-obese urban Philadelphia female adolescents. Obes Res. 2001; 9(2):112-8.

10. Barbosa LB, Vasconcelos SM, Correia LO, Ferreira RC. Nutrition knowledge assessment studies in adults: a systematic review. Ciên Saúde Coletiva. 2016; 21(2):449-62.

11. Larson I, Lissner L, Wilhelmsen L. The "Green Keyhole" revisited: nutritional knowledge may influence food selection. Eur J Clin Nutr. 1999; 53(10):776-80.

12. Dallongeville J, Marécaux N, Cottel D, Bingham A, Amouyel P. Association between nutrition knowledge and nutritional intake in middle-aged men from Northern France. Public Health Nutr. 2001; 4(1):27-33.
13. Parmenter K, Wardle J. Development of a general nutrition knowledge questionnaire for adults. Eur J Clin Nutr. 1999; 53(4):298-308

14. Deolindo SM, de Moraes CB. Consumo alimentar e conhecimento nutricional de idosos praticantes de hidroginástica. Disciplinarum Scientia | Saúde. 2015; 16(1):101-111.

15. Scherer R, Scherer F, Conde SR, Dal Bosco SM. Nutritional status and prevalence of chronic diseases among elderly in the countryside of Rio Grande do Sul state, Brazil. Rev Bras Geriatr Gerontol. 2013; 16(4):769-779.

16. Prates RE, da Silva ACP. Avaliação do conhecimento nutricional e de hábitos alimentares de pacientes com doenças crônicas não transmissíveis em hospital particular no sul do Brasil. Rev Assoc Bras Nutrição-RASBRAN. 2013; 5(1):21-7.

17. Instituto Brasileiro de Geografia e Estatística. IBGE. Pesquisa de Orçamentos Familiares 2008-2009: Avaliação do Estado nutricional: Perfil antropométriconutricional da população adulta em 2008-2009.

18. Kearns K, Dee A, Fitzgerald AP, Doherty E, Perry IJ. Chronic disease burden associated with overweight and obesity in Ireland: the effects of a small BMI reduction at population level. BMC Public Health. 2014; 14:143.

19. Faccin AP, Alves MK, Macedo RCO. Perfil antropométrico e alimentar e o conhecimento nutricional de atletas de voleibol. Rev Bras Nutr Esp. 2017; 11(63):259-264.

20. Furlan AS, Rodrigues L. Consumo de polifenóis e sua associação com conhecimento nutricional e atividade física. Rev Bras Med Esporte. 2016; 22(6):461-464.

21. O'Brien G, Davies M. Nutrition Knowledge and body mass Index. Health Educ Res. 2006; 22(4):571-5.

22. Almeida JC, Siqueira VS, Piantino CB. Avaliação do conhecimento em nutrição de mulheres fisicamente ativas e sua associação com características sociodemográficas e estado nutricional. Rev Bras Obes Nutr Emagr. 2017; 11(64):232-239.

23. Souza LV, Ornellas FH. Avaliação do conhecimento nutricional de indivíduos eutróficos, sobrepesos e obesos e sua associação com o estado nutricional. Rev Bras Obes Nutr Emagr. 2011; 5(26):40-47.

24. Thakur N, D'Amico F. Relationship of nutrition knowledge and obesity in adolescence. Fam Med. 1999; 31(2):122-7.

25. Mamun AA, O'Callaghan MJ, Williams G, Najman JM. Television watching from adolescence to adulhood and its association with BMI, waist circumference, waist-to-hip ratio and obesity: a longitudinal study. Public Health. 2013; 16(1):54-64.

26. Pereira TS, Pereira RC, Angelis-Pereira MC de. Influência de intervenções educativas no conhecimento sobre alimentação e nutrição de adolescentes de uma escola pública. Ciênc Saúde Coletiva. 2017; 22(2):427-435

27. Alvarez TS, Zanella MT. Impacto de dois programas de educação nutricional sobre o risco cardiovascular em pacientes hipertensos e com excesso de peso. Rev Nutr. 2009; 22(1):71-79.

28. Parmenter K, Waller J, Wardle J. Demographic variation in nutrition knowledge in England. Health Edu Res. 2000; 15(2):163-74. 